\title{
Extreme weather affects Peregrine Falcon (Falco peregrinus tundrius) breeding success in South Greenland
}

\author{
Linnéa CARLZON ${ }^{1}$, Amanda KARLSSON ${ }^{1 *}$, Knud FALK ${ }^{2}$, Antonia \\ LIESS $^{1} \&$ Søren MøLLER ${ }^{3}$
}

Received: March 29, 2018 - Revised: September 26, 2018 -Accepted: September 28, 2018

This is a contribution submitted to the Proceedings of the World Conference on the Peregrine Falcon in Budapest in September 2017.

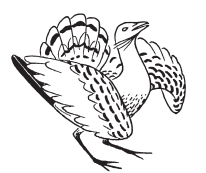

Carlzon, L., Karlsson, A., Falk, K., Liess, A. \& Møller, S. 2018. Extreme weather affects Peregrine Falcon (Falco peregrinus tundrius) breeding success in South Greenland. - Ornis Hungarica 26(1): 38-50. DOI: 10.1515/orhu-2018-014 Falcon, we investigated the relationship between extreme weather events and Peregrines' breeding success in South Greenland. We defined three variables - number of days with extremely low temperatures, extreme precipitation, consecutive rainy days - and an additive variable, total days with extreme weather, and tested their relationship with Peregrines' breeding success (measured as young per site and nest success) over a 33 year study period. Breeding success was negatively influenced by the number of days with extreme weather and extremely low temperature. The strongest relationship found was total days with extreme weather in the entire breeding season, which explained $22 \%$ and $27 \%$ of the variation in nest success and young per site, respectively. The number of days with extreme weather in our study related to fluctuations in the North Atlantic Oscillation (NAO). Thus, with a strengthening of the NAO, linked to climate change, more extreme weather may occur in the Arctic and induce increased variation in Peregrines' breeding success. Our data did not allow us to pinpoint when in the breeding cycle inclement weather was particularly harmful, and we recommend finer-scale research (e.g. automated nest cameras) to better monitor the species-specific effects of rapidly changing climate.

Keywords: Arctic, climate change, productivity

Összefoglalás A klímaváltozás vándorsólymokra gyakorolt lehetséges hatásainak jobb megértése érdekében a faj költési sikerének és a szélsőséges időjárási események kapcsolatát vizsgáltuk Dél-Grönlandon. Négy változót határoztunk meg - szélsőségesen alacsony hömérsékletủ napok száma, túlzott csapadékmennyiség, egymást követő esős napok száma - kiegészítve a szélsőséges napok teljes számával, melyeket a vándorsólymok költési sikerével (fiókák száma és a fészek sikeressége) vetettünk össze, egy 33 évet felölelő adatsor alapján. A költés sikeressége egyaránt negatív összefüggést mutatott a szélsőséges időjárású, valamint az alacsony hőmérsékletủ napok számával. A legerősebb összefüggést mutató változó a fészek sikerességében és a fiókák számában mutatkozó változatosság 22 , illetve $27 \%$-át magyarázta. A szélsőséges időjárású napok száma összefüggést mutat az Észak-atlanti Oszcillációs Rendszerrel (NAO). Ezért a NAO erősödésével, mely a klímaváltozáshoz szorosan kapcsolódik, egyre szélsőségesebb időjárás várható a sarki régióban, amely egyre inkább befolyásolhatja a vándorsólymok költési sikerét. Adataink nem tették lehetővé azt, hogy pontosabban meghatározzuk, hogy a költési időszak melyik szakaszában különösen fenyegetőek ezek a változások, ezért finomabb skálán kivitelezett kutatások (pl. fészekkamerák alkalmazása) javasolt a gyorsan változó klíma különböző fajokra gyakorolt hatásának vizsgálatára. 
${ }^{1}$ Rydberg Laboratory of Applied Science, School of Business, Engineering and Science, Halmstad University,
30118 Halmstad, Sweden, e-mail: linnea.carlzon@gmail.com
${ }^{1}$ Rydberg Laboratory of Applied Science, School of Business, Engineering and Science,Halmstad University,
30118 Halmstad, Sweden, e-mail: amanda_karlson_335@hotmail.com
${ }^{1}$ Rydberg Laboratory of Applied Science, School of Business, Engineering and Science,Halmstad University,
30118 Halmstad, Sweden,e-mail: antonia.liess@hh.se
${ }^{2}$ www.vandrefalk.dk, Ljusstöparbacken 11A, 11765 Stockholm, Sweden, e-mail: knudfalk@hotmail.com
${ }^{3}$ Roskilde University Library, Universitetsvej 1,4000 Roskilde, Denmark, e-mail: moller@ruc.dk
${ }^{*}$ corresponding author

\section{Introduction}

Past and current climate change, caused by anthropogenic emissions, has led to increasing surface temperatures, more frequent and intense temperature extremes as well as increased variability in precipitation (Parmesan 2006, Stocker et al. 2013). For much of the Arctic, climate change scenarios predict higher precipitation levels and increased and more varied temperatures, which in turn will cause more precipitation to fall as rain (Stocker et al. 2013). In addition, the North Atlantic part of the Arctic is affected by a strengthening of the North Atlantic Oscillation (NAO). The NAO is caused by fluctuations in atmospheric sea-level pressure differences between the subtropical region (centered in the Azores) and the subpolar region (centered in Iceland). This might result in more extreme weather events due to the disruptive influence of NAO on temperature and precipitation patterns (NOAA 2018). This drastic change in the Arctic climate destabilizes species' communities in the region. Examining how Arctic species respond to weather variability can help predict how species composition may change in the future (Cleasby et al. 2017). The Peregrine Falcon (Falco peregrinus) is a suitable study species since it is a well-studied Arctic top predator with long term monitoring data on productivity and occupancy from different regions, and sensitive to inclement weather during critical stages of the breeding cycle (Olsen \& Olsen 1988, Anctil et al. 2014).

Falco peregrinus tundrius, (further the Peregrine) arrives in May to the subarctic southern parts of Greenland from its wintering locations in Latin America (Vorkamp et al. 2017). Its nesting sites are often located on sheltered ledges on steep cliff walls, for protection from predatory mammals and harsh weather (Falk et al. 1986, Wightman \& Fuller 2005). In South Greenland the Peregrine's breeding season starts in mid-May and, on average, chicks hatch in early July (Falk \& Møller 2017). However, over the past three decades the Peregrine's breeding success has been highly variable in South Greenland. This may be explained by variations in the frequency of extreme weather events related to climate change and the increased manifestation of the NAO. Over the same period, the breeding has been starting slightly earlier which might indicate a response to a warming climate (Parmesan 2006, Fletcher et al. 2013). Even the NAO may or may not affect the Peregrine's shift towards earlier arrival and may consequently result in earlier breeding and hatching (review in Haest et al. 2017). The long-term consequence of earlier breeding and hatching may be a mismatch between the Peregrine's highest food demand during the breeding season and peak prey abundance, which may lead to reduced breeding success (Parmesan 2006, Sullivan et al. 2015). 
Although the Peregrine Falcon is a well-studied top predator in the Arctic, only a few works have identified how and if weather events - and possible interannual variation linked to the NAO - may affect the breeding populations. However, Anctil et al. (2014) found that number of days with extreme rainfall had increased in Arctic Canada, negatively affecting Peregrine productivity. Breeding success depends on food supply from the moment the adult birds arrive at their nesting sites, and even the body reserves the female is carrying when she arrives from her wintering and migration foraging sites (Franke 2017). Harsh weather may inhibit the breeding pair from efficiently hunting their swift avian prey, since avian prey may be less active and available during heavy rains (and strong winds). Rainfall and extreme temperature may further increase movement costs, complicate foraging, and disrupt egg incubation (Öberg et al. 2015). After the chicks hatch, extreme weather may even directly affect nestling survival. During their first 21 days, nestlings are vulnerable to wet and cold, due to lack of thermoregulation (Bradley et al. 1997, Anctil et al. 2014, Pipoly et al. 2013). In addition to these direct weather effects, starvation among nestlings due to parents' limited foraging success, may be an indirect consequence of harsh weather. Therefore, studying how breeding success is influenced by variability in rainfall and temperature is important for understanding how future climate changes and weather extremes may affect the population of this bird of prey.

In order to understand the potential effects of climate change on the Peregrine, we investigate whether NAO affects the frequency and duration of extreme weather events in South Greenland, and whether these extreme weather events in turn affect the breeding success of the Peregrine Falcon population in this region. This study will answer the four following questions:

1.Does strengthening of the NAO during the breeding season influence number of days with extreme weather during this period?

2. Does an increased number of days with extremely low temperatures influence breeding success?

3.Do extreme precipitation and consecutive rainy days influence breeding success?

4. Is there any period during the breeding season when extreme weather events are particularly linked to breeding success?

\section{Materials and methods}

\section{Study Species and Area}

The Peregrine is a top predator with few enemies (Mearns \& Newton 1988, Wightman \& Fuller 2005) with a distribution across all major land masses, except New Zealand and Antarctica, and with many subspecies adapted to different climate regimes around the globe (White et al. 2013). Peregrines can reach a maximum age of 12-15 years, have an average generation time of 6.8 years, and females normally lay 2-4 eggs (Park et al. 2011, White et al. 2013). The worldwide population of the Peregrine Falcon is estimated at 140,000 individuals (subspecies included) and is listed as least concern (LC) on the IUCN Red List of 


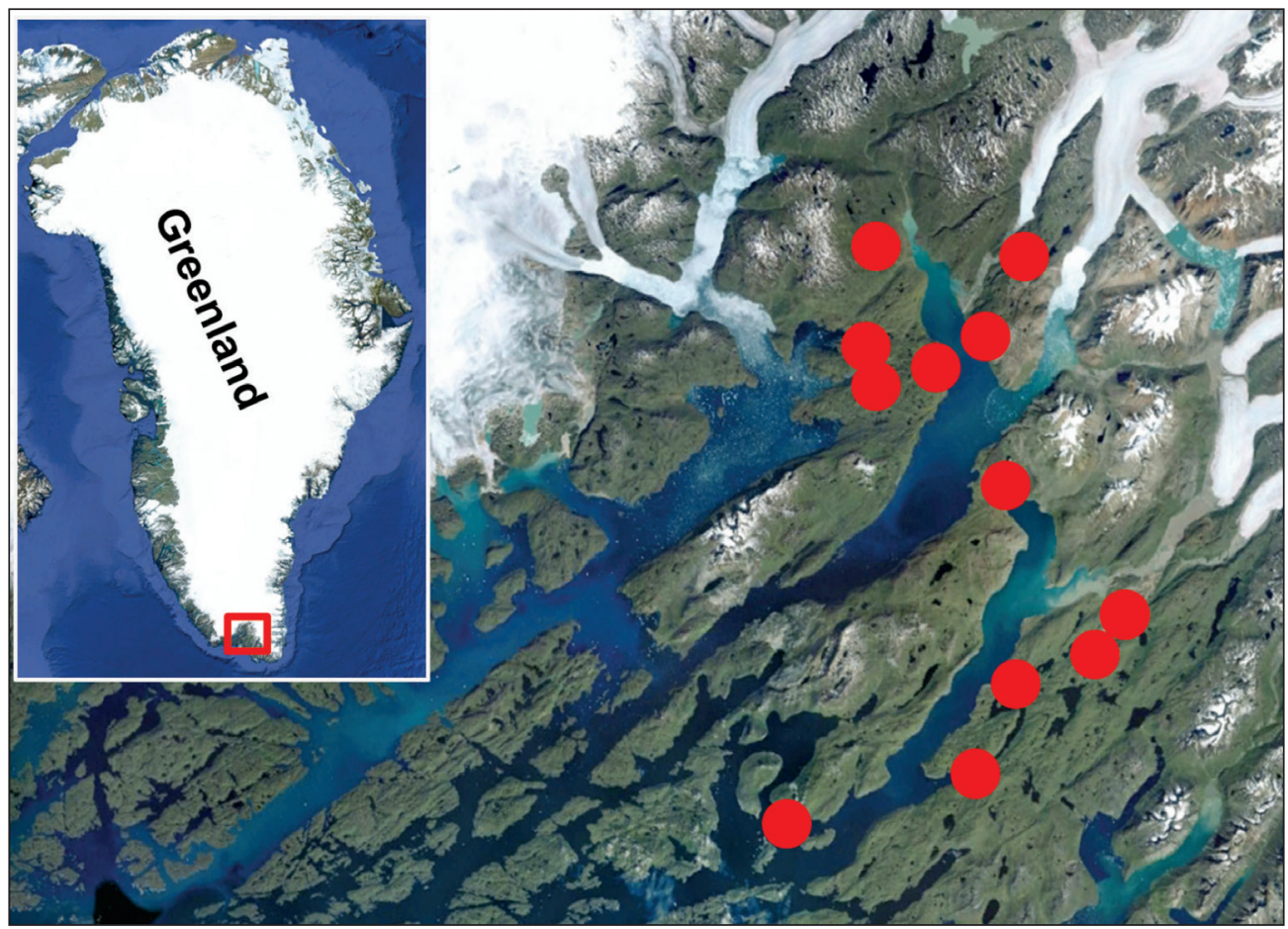

Figure 1. The 12 sample sites along Tunulliarfik and Igaliku fjords, each site may hold a territorial pair of Peregrines, some of which will produce young in any given year. Data was collected between 1981 and 2015. Picture modified after Google maps

1. ábra A 12 mintavételi pont elhelyezkedése Tunulliarfik és Igaliku fjordok mentén. Minden mintapont egy-egy vándorsólyom pár területére esik, amely párok az adott évben neveltek fiókákat. Az adatok 1981 és 2015 között lettek gyűjtve. A képek a Google térképek felhasználásával készültek

Threatened Species (BirdLife International 2016). Greenland holds 100-500 breeding pairs (Falk \& Møller 1988, Boertmann 2008). In South Greenland, the Peregrine feeds almost exclusively on migratory passerines (Falk et al. 1986). The survey area is located in Southwestern Greenland and the Peregrine monitoring sites are distributed across the coastal and inland areas of Tunulliarfik and Igaliku fjords (Figure 1).

Known Peregrine breeding sites were surveyed 1 to 3 times per year in June and/or July, sometimes also in August. During surveys of active nests, the number of eggs and/or young was recorded and the timing of breeding estimated based on age of nestlings (Clum et al. 1996) or on the developmental stage of eggs (White et al. 2002).

For this study, we defined three periods of the breeding cycle. Firstly, the pre-laying period, which begins in May when the Peregrines arrive to their breeding grounds in South Greenland and (re)occupy territories and mate. Secondly, the approximately 33-day long incubation period roughly corresponding to the month of June. Thirdly the nestling period lasting throughout July (Falk et al. 1986). The mean hatching date is the $3^{\text {rd }}$ of July (Falk et al. 1986, Falk \& Møller 2017). 


\section{NAO and Weather Data}

NAO-index data for 1981-2015 were downloaded from NOAA/Climate Prediction Center (NOAA 2012) for the months of May, June and July (Peregrine breeding season). Local weather data collected from weather stations in Qaqortoq and Narsarsuaq were available from The Danish Meteorological Institute (Cappelen 2016). We calculated mean daily temperature and total precipitation (for the 24-hour period) for the three breeding cycle periods: pre-laying (May), incubation (June) and nestling period (July). Missing precipitation values in the data set were estimated based on mean values of surrounding measurements; if precipitation and temperature values were missing for more than 24 hours, values for that day were omitted from analyses.

In order to test whether extreme weather events are particularly harmful for the Peregrines breeding success during any particular period of the breeding season (pre-laying, incubation or nestling period), we estimated the extreme weather variables for each period (i.e. May, June and July) as well as for the breeding season as a whole (May-July). We calculated four extreme weather variables 1) extreme low temperatures, 2) extreme precipitation, 3) consecutive rainy days and 4) total days with extreme weather (cumulative variable), based on Bradley et al. (1997), Fisher et al. (2015) and Pipoly et al. (2013). Extreme low temperatures were defined as all values under the $10^{\text {th }}$ percentile of the average daily mean temperature (pre-laying between $\left[-9.7{ }^{\circ} \mathrm{C}\right.$ and $\left.10.3{ }^{\circ} \mathrm{C}\right]$, incubation between $\left[1.5^{\circ} \mathrm{C}\right.$ and $\left.5.5^{\circ} \mathrm{C}\right]$ and for nestling period between $\left[4.9^{\circ} \mathrm{C}\right.$ and $\left.8.1^{\circ} \mathrm{C}\right]$ ). Extreme precipitation was defined by adding the standard deviation (SD) to the average mean precipitation for each period (only days with rain over $0.1 \mathrm{~mm}$ included) as follows: pre-laying (mean $+\mathrm{SD}=5.8 \mathrm{~mm}+8.0$

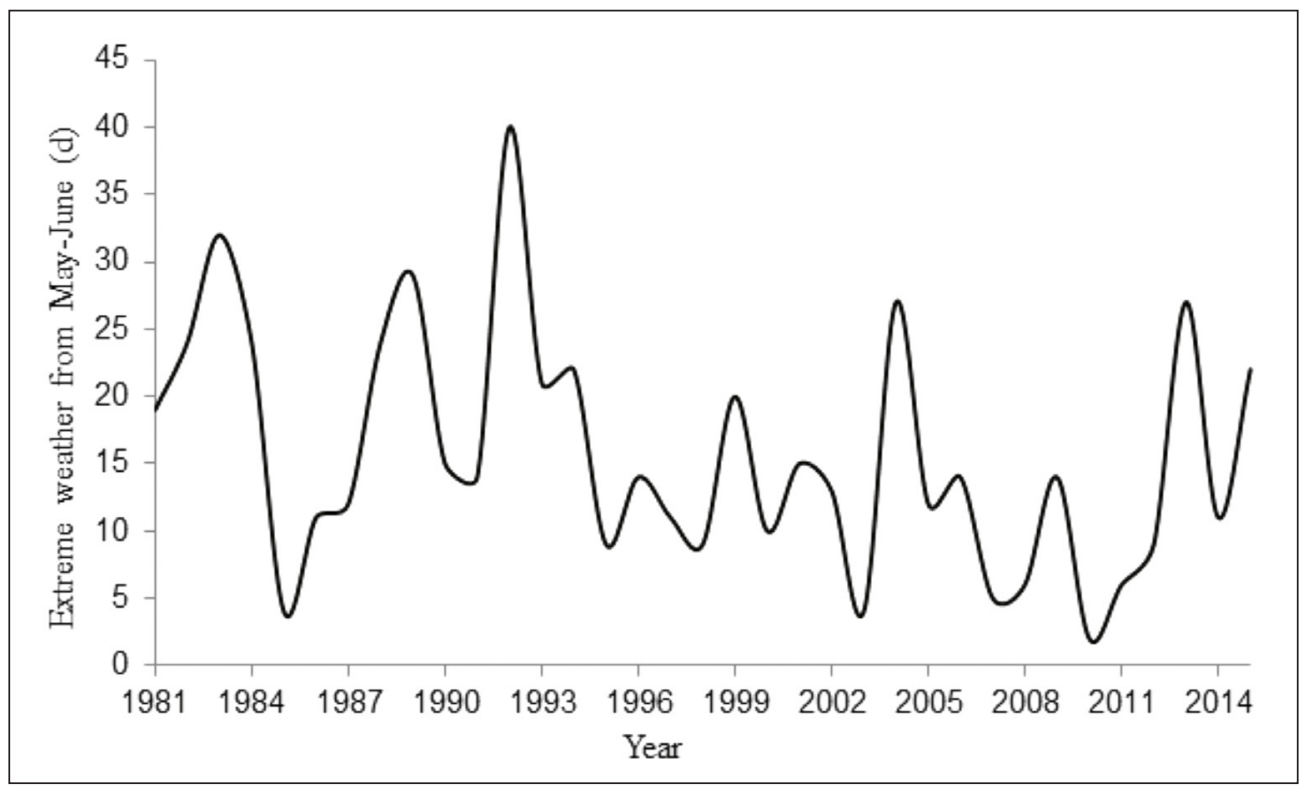

Figure 2. Variation in days with extreme weather over the study period 1981-2015

2. ábra A szélsőséges időjárású napok megoszlása az 1981-2015 közötti vizsgálati időszakban 
$\mathrm{mm}$ ), incubation (mean $+\mathrm{SD}=6.5 \mathrm{~mm}+10.0 \mathrm{~mm}$ ) and nestling period (mean $+\mathrm{SD}=7.0$ $\mathrm{mm}+9.9 \mathrm{~mm}$ ). Approximately $10 \%$ of all days with rain were extreme. Two or more days with continuous rain and with equal or higher than mean precipitation were defined as consecutive rainy days. In order to understand the overall additive effect of all extreme weather events on breeding success we added up all days with extreme weather events into one variable: total extreme days. This variable showed high inter-annual fluctuation but no overall change over time (Figure 2).

\section{Response Variables}

We used two response variables in this study to represent the Peregrine's breeding success, (1) young per site and (2) nest success. Young per site is the total number of young divided by the monitored sites (known territories) for each monitored year $(n=33)$. Nest success is the proportion of territorial pairs (in \%) producing young during each monitored year (n $=33$ ).

\section{Data analyses}

Due to the small data set $(n=33)$, we used a statistical approach where each of our hypotheses was directly tested with univariate or multiple linear regressions. With a larger data set, we could have used a more comprehensive approach, such as analyzing the predictive power of a large number of potential weather-related predictor variables (main effects and interactions) in conjuncture with a model simplification approach according to Aikaike's Information Criterion to determine the best model. However, this approach could not be used here since extreme weather variables are often strongly correlated, such as extremely low temperature with extreme precipitation in July $\left(\mathrm{R}^{2}=0.43\right.$, in our data set), and they can therefore not be used together in the same model.

We thus proceeded as follows: In order to answer question 1, linear regression analyses for each period (pre-laying [May], incubation [June] and nesting period [July]) tested whether extreme weather was connected to the strength of the NAO. In order to answer question 2 and 3, we used further linear regression analyses to test the effects of extremely low temperature, extreme precipitation, consecutive rainy days and total days with extreme weather on young per site and nest success for each of the different breeding seasons, as well as for the breeding season as a whole. In order to test question 4, whether breeding success was more sensitive to the different extreme weather events during any particular breeding period; $\mathrm{R}^{2}$-values from all regression analyses, conducted separately for each period (May, June and July) were compared to each other as well as to the $\mathrm{R}^{2}$-values for the breeding season as a whole. We used the statistical software IBM SPSS Statistics 24 for all statistical analyses. Significance levels were set at $a=0.05$ and data were $\log 10(x)$ transformed to achieve a normal distribution. 


\section{Results}

We found a significant positive relationship between total extreme days and NAO during all three defined periods of the breeding season: the pre-laying period in May $\left(\mathrm{P}<0.001, \mathrm{R}^{2}=\right.$ $0.32)$, during the incubation period in June $\left(\mathrm{P}<0.001, \mathrm{R}^{2}=0.44\right)$ and during the nestling period in July $\left(\mathrm{P}=0.005, \mathrm{R}^{2}=0.18\right)$.

We also found significant relationships between several of the extreme weather variables and the breeding success of the Peregrine (Table 1, Figure 3, 4). When analyzing the entire breeding season, nest success was significantly negatively related to extreme precipitation

Table 1. Relationship between extreme weather overall and during the different periods of the breeding season (May, June or July) and Peregrine breeding success (nest success and young per site). $R^{2}$ represents the proportion of variation explained by the predictor variable, $\mathrm{P}$ represents the $\mathrm{P}$-value and the relationship whether the relationship between the variables is positive or negative

1. tábla A szélsőséges időjárási tényezők és a vándorsólymok költési sikerének (fészek sikeressége és fiókák száma) kapcsolata, összességében és a költési időszak egyes periódusaiban (május, június és július). $R^{2}$ - a független változó magyarázó ereje, $\mathrm{P}$ - szignifikancia érték. A változók közötti összefüggés irányát + vagy - jelöli

\begin{tabular}{|c|c|c|c|c|c|c|}
\hline & \multicolumn{3}{|c|}{ Nest Success } & \multicolumn{3}{|c|}{ Young per site } \\
\hline & $\begin{array}{l}\text { Relationship } \\
(+ \text { or }-)\end{array}$ & $\mathrm{R}^{2}$ & P-value & $\begin{array}{l}\text { Relationship } \\
(+ \text { or }-)\end{array}$ & $\mathrm{R}^{2}$ & P-value \\
\hline \multicolumn{7}{|l|}{ Breeding Season (May - July) } \\
\hline Extreme low temperature (d) & - & 0.207 & 0.004 & - & 0.202 & 0.004 \\
\hline Extreme precipitation (d) & - & 0.090 & 0.045 & - & 0.129 & 0.020 \\
\hline Consecutive rainy days (d) & & 0.002 & 0.405 & & 0.015 & 0.250 \\
\hline Total extreme days (d) & - & 0.221 & 0.003 & - & 0.271 & 0.001 \\
\hline \multicolumn{7}{|l|}{ Pre-laying period ( May) } \\
\hline Extreme low temperature $(\mathrm{d})$ & - & 0.098 & 0.038 & - & 0.177 & 0.007 \\
\hline Extreme precipitation (d) & & 0.035 & 0.150 & & 0.039 & 0.136 \\
\hline Consecutive rainy days (d) & & 0.001 & 0.439 & & 0.024 & 0.194 \\
\hline Total extreme days (d) & - & 0.099 & 0.037 & - & 0.184 & 0.006 \\
\hline \multicolumn{7}{|l|}{ Incubation period ( June) } \\
\hline Extreme low temperature (d) & - & 0.155 & 0.012 & - & 0.155 & 0.012 \\
\hline Extreme precipitation (d) & & 0.064 & 0.077 & & 0.083 & 0.052 \\
\hline Consecutive rainy days (d) & & 0.015 & 0.250 & & 0.040 & 0.132 \\
\hline Total extreme days (d) & - & 0.199 & 0.005 & - & 0.224 & 0.003 \\
\hline \multicolumn{7}{|l|}{ Nestling period ( July) } \\
\hline Extreme low temperature (d) & & 0.051 & 0.104 & & 0.021 & 0.210 \\
\hline Extreme precipitation (d) & & 0.007 & 0.325 & & 0.020 & 0.218 \\
\hline Consecutive rainy days (d) & & 0.005 & 0.343 & & 0.018 & 0.227 \\
\hline Total extreme days (d) & & 0.028 & 0.178 & & 0.013 & 0.266 \\
\hline
\end{tabular}



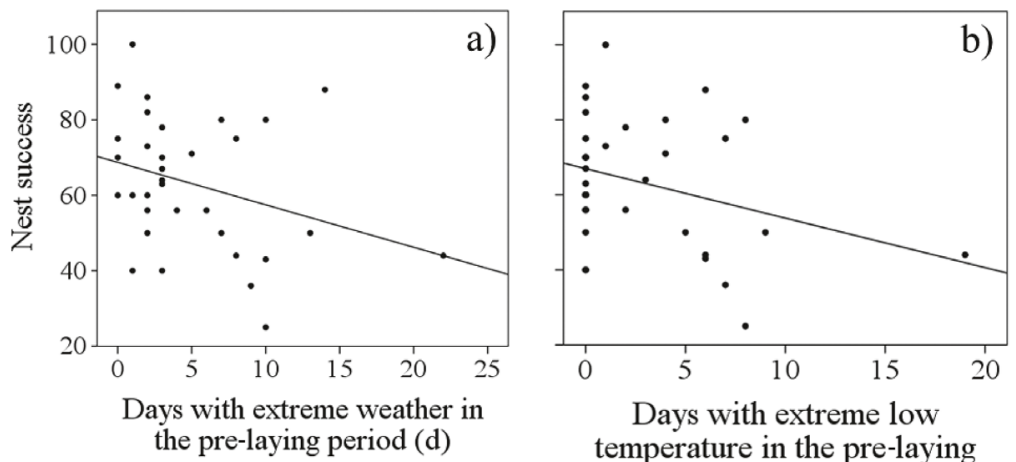
period (d)

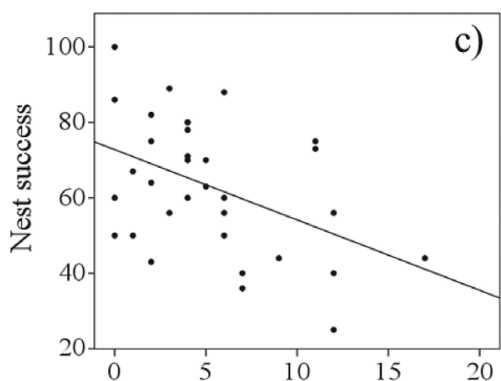

Days with extreme weather in incubation period (d)

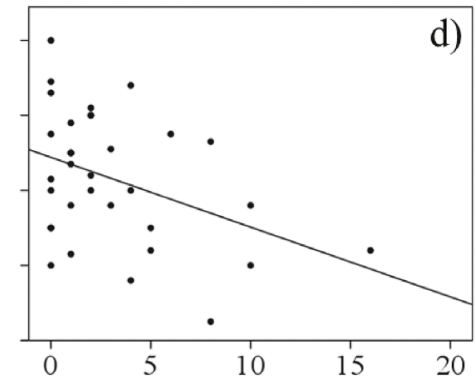

Days with extreme low temperature in the incubation period (d)
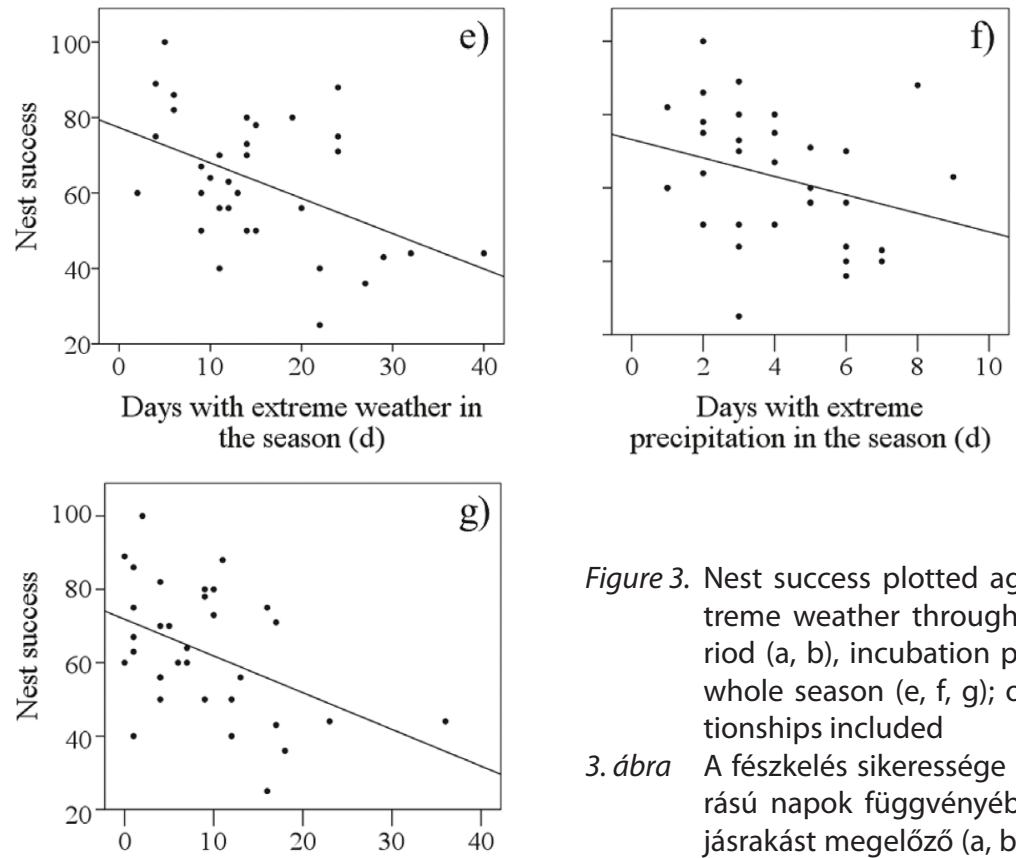

Days with extreme low temperature in the season (d)

Figure 3. Nest success plotted against days with extreme weather through the pre-laying pe$\operatorname{riod}(a, b)$, incubation period $(c, d)$ and the whole season (e, $f, g)$; only significant relationships included

3. ábra A fészkelés sikeressége a szélsőséges időjárású napok függvényében ábrázolva, a tojásrakást megelőző $(a, b)$, a kotlási $(c, d)$ és a teljes $(e, f, g)$ időszakban. Csak a szignifikáns eredmények vannak feltüntetve 

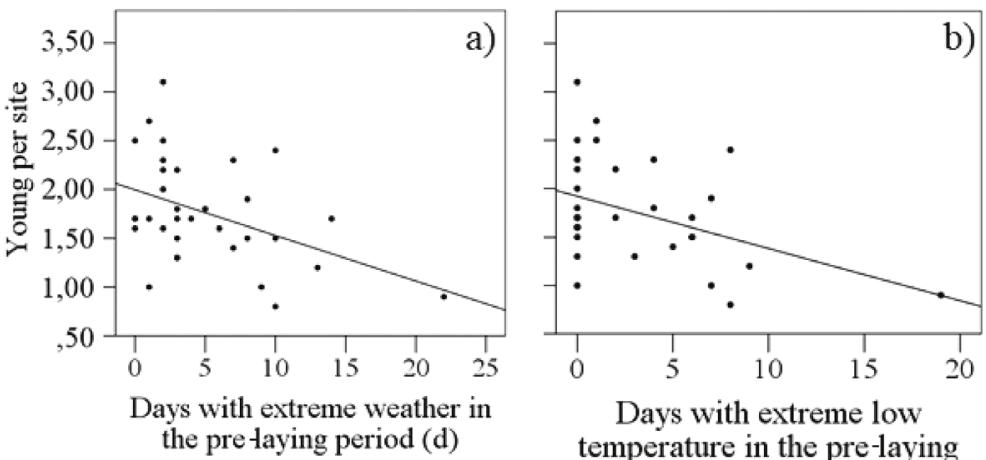

Days with extreme low temperature in the pre-laying period (d)

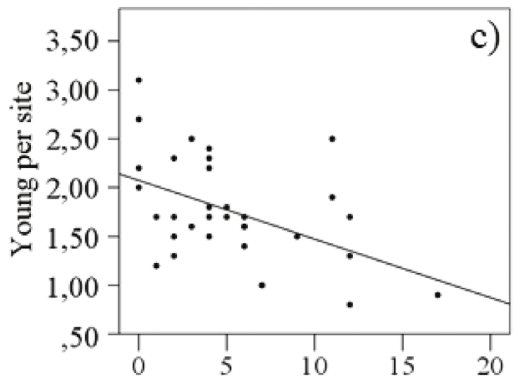

Days with extreme weather in the incubation period (d)

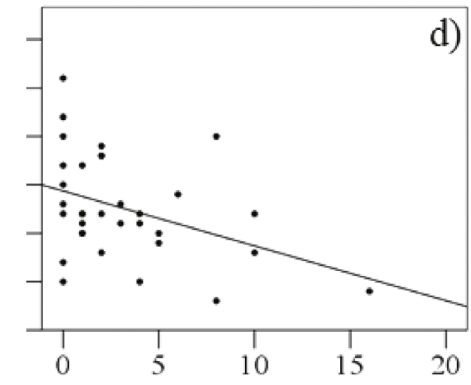

Days with extreme low temperature in the incubation period (d)

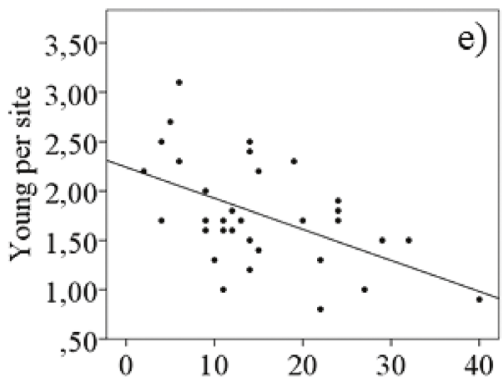

Days with extreme weather in the season (d)

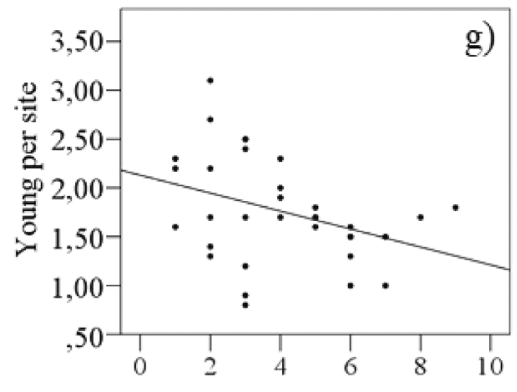

Days with extreme precipitation in the season (d)

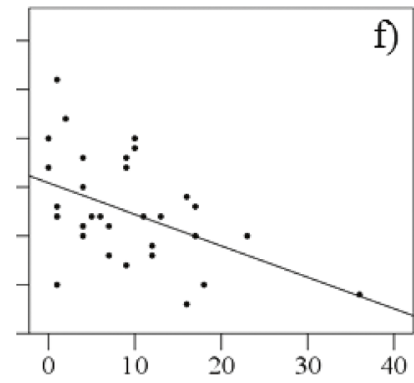

Days with extreme low temperature in the season (d)

Figure 4. Young per site plotted against days with extreme weather through the pre-laying period $(a, b)$, incubation period $(c, d)$ and the whole season $(e, f, g)$; only significant relationships included

4. ábra A fiókák száma a szélsőséges időjárású napok függvényében ábrázolva, a tojásrakást megelőző $(a, b)$, a kotlási $(c, d)$ és a teljes (e, $\mathrm{f}, \mathrm{g}$ ) időszakban. Csak a szignifikáns eredmények vannak feltüntetve 
(Figure 3f), extreme low temperatures, (Figure 3g) as well as the additive variable (including temperature and rain) total days with extreme weather (Figure 3e). Young per site was dependent on extreme precipitation (Figure 4g), extreme low temperatures (Figure 4f) and total days with extreme weather (Figure 4e) in the breeding season (Table 1). However, we found no significant relationship between breeding success and the predictor variable consecutive rainy days $(\mathrm{P}>0.05)$.

When considering weather in the three defined periods of the breeding season separately, extreme low temperature and total extreme days emerged as factors with significant relationships with both the dependent variables in the pre-laying period and the incubation period (Table 1); no significant relationships with weather in the nestling period was found. Total extreme days in the incubation period was the strongest predictor of nest success as well as of young per site.

Our results showed that the breeding success of the Peregrines is linked to extreme weather events (Figure 2, 3) and the strongest predictor for overall breeding success the additive weather variable "total extreme days in the season", explains $22 \%$ and $27 \%$ of the variation in nest success and young per site, respectively.

\section{Discussion}

The total number of extreme days in all breeding periods (May, June and July) significantly correlated with the NAO index (answering question 1). The number of days with extreme low temperature negatively affected breeding success during the whole breeding season, as well as separately for the pre-laying and the incubation period, but not the nestling period (answering question 2). Extreme precipitation (but not consecutive rainy days) negatively affected breeding success during the whole breeding season. However, no significant relationship was detected for extreme precipitation or consecutive rainy days on breeding success during any of the separate breeding periods (May, June or July) (answering question 3). Last, we found that extreme weather events early during the breeding season (pre-laying and incubation) had stronger effects on breeding success than extreme weather during nestling period (answering question 4).

We found the strongest relationship between Peregrine breeding success and the additive weather variable "total number of extreme days" measured over the whole breeding season. This is not surprising for several reasons. Firstly, rain events are usually associated with cold days in the study area (although cold, dry days do occur), so the combined factor total number of extreme days captures the combined power of days with bad weather. Secondly, the response variables on Peregrine productivity (young per site and nest success) are annual means only and, thirdly, overall breeding success measures reproduction and survival integrated over the whole breeding period and does not include any information on when in the breeding season the breeding attempt failed. Contrary to expectations from other studies, where rainfall has been identified as a cause for avian mortality during the nestling period, including Peregrines (Mearns \& Newton 1988, Bradley et al. 1997, Anctil et al. 2014, McDermott \& DeGroote 2016), extreme precipitation in our study showed a significant relationship for the entire breeding period and not for a specific period. 
Since South Greenland can experience several consecutive days of wet, foggy weather, presumably affecting Peregrine food accessibility and thus posing a risk of exposure to eggs and young, we expected to find a negative effect of consecutive rainy days on the Peregrines' breeding success. We found no such effect which may be because we applied too conservative criteria for consecutive rainy days: we only included days with mean precipitation or above. In addition, there is local spatial variations in weather, which are not well captured in our data since there are only two weather stations in the area.

The effect of weather on productivity is mediated by the parents' selection of a suitable protective nest ledge and Peregrines frequently return to successful nest sites and desert nesting sites that are exposed to direct rainfall or that have become wet or flooded already during the pre-laying period (Olsen \& Olsen 1988, Bruggeman et al. 2016). However, there is a limit to how effective this strategy is (Olsen \& Olsen 1988, McDonald et al. 2004): an experimental Arctic study reduced nesting mortality through rain events by installing nest boxes (Anctil et al. 2014). This shows clearly that nest mortality is, at least partly, caused by exposure to rain. Especially small nestlings in the Arctic are at risk from hypothermia caused by low temperatures and humidity due to their lack of thermoregulation (Fletcher $e t$ al. 2013, Lehikoinen et al. 2013, Pipoly et al. 2013, Anctil et al 2014), but even in temperate regions a single daylong intensive rainfall event can kill 2 week-old young (P. Lindberg and N. P. Andreasen, pers. com.). We conclude that extreme rain events are likely to affect peregrines' breeding success. However, it is not clear under which circumstances and in combination with which other factors extreme precipitation is most detrimental to breeding success. Other weather phenomena besides the NAO may also influence number of days with extreme weather; nevertheless we can conclude that strengthening of the NAO is one factor that is influencing the local weather patterns and that NAO may possibly be used as a predictor for Peregrine productivity.

We have shown that locally extreme weather events are affecting Peregrine productivity negatively in subarctic South Greenland, but our data do not allow finer identification of critical periods of the breeding cycle in order to pinpoint the specific mortality events or the Peregrine's ability to adapt to these extreme weather events. Fine-resolution information on individual nesting failures - timing in the breeding cycle, age of eggs/young - would be needed. This calls for simple upgrades to existing field procedures by upscaling the use of automated recordings by cameras (Anctil et al. 2014, Robinson \& Prostor 2017) which we would recommend for any long-term studies of raptors, partly in order to monitor the effects of rapidly changing climate.

\section{Acknowledgements}

The field work on Falcon ecology over several decades has been funded by a range of private funds - all listed at http://vandrefalk.dk/sponsorer_eng.shtml.We thank T. Carlzon and P. Ceder for constructive criticism and valuable feedback. 


\section{References}

Anctil, A., Franke, A. \& Bêty, J. 2014. Heavy rainfall increases nestling mortality of an arctic top predator: experimental evidence and long-term trend in Peregrine Falcons. - Oecologia 174(3): 1033-1043. DOI: 10.1007/ s00442-013-2800-y

BirdLife International 2016. Falco peregrinus. The IUCN Red List of Threatened Species 2016: e. T45354964A95143387. - http://dx.doi.org/10.2305/IUCN.UK.2016-3.RLTS.T45354964A95143387.en. (Last accessed on 2017-05-10)

Boertmann, D. 2008. Grønlands Rødliste - 2007 [Greenland Red List - 2007]. - Danmarks Miljøundersøgelser, Aarhus Universitet og Grønlands Hjemmestyre: 156. (in Danish)

Bradley, M., Johnstone, R., Court, G. \& Duncan, T. 1997. Influence of weather on breeding success of Peregrine Falcons in the Arctic. - The Auk 114(4): 786-791. DOI: 10.2307/4089303

Bruggeman, J. E., Swem, T., Andersen, D. E., Kennedy, P. L. \& Nigro, D. 2016. Multiseason occupancy models identify biotic and abiotic factors influencing a recovering Arctic Peregrine Falcon Falco peregrinus tundrius population. - Ibis 158(1): 61-74. DOI: 10.1111/ibi.12313

Cappelen, J. 2016. DMI Report 16-08 Weather observations from Greenland 1958-2015 - Observation data with description. - Report/ Danmarks Meteorologiske Institut. - http://www.dmi.dk/fileadmin/user_upload/Rapporter/TR/2016/DMIRep16-08.pdf (Last accessed on 2017-03-06)

Cleasby, I. R., Bodey, T. W., Vigfusdottir, F., McDonald, J. L., McElwaine, G., Mackie, K., Colhoun, K. \& Bearhop, S. 2017. Climatic conditions produce contrasting influences on demographic traits in a long-distance Arctic migrant. - Journal of Animal Ecology 86(2): 285-295. DOI: 10.1111/1365-2656.12623

Clum, N., Harrity, P. \& Weck, H. 1996. Aging young Peregrines. - In: Cade, T. J., Enderson, J. H. \& Linthicum, J. (eds.) Guide to Management of Peregrine Falcons at the Eyrie. - The Peregrine Fund, pp. 37-63.

Falk, K. \& Møller, S. 2017. Field report 2017: Monitoring of the Peregrine Falcon population in South Greenland. - http://vandrefalk.dk/feltrap/rap2017.pdf (Last accessed on 2018-03-21)

Falk, K. \& Møller, S. 1988. Status of the Peregrine Falcon in South Greenland: Population Density and Reproduction. - In: Cade, T. J., Enderson, J. H., Thelander, C. G. \& White, C. M. (eds.) Peregrine Falcon populations: Their management and recovery. - Proc. 1985 Peregrine Conf., Sacramento, The Peregrine Fund, Inc., pp. 37-43.

Falk, K., Møller, S. \& Burnham, W. A. 1986. The Peregrine Falcon Falco peregrinus in South Greenland. - Dansk Ornitologisk Forenings Tidsskrift 80: 113-120.

Fisher, R. J., Wellicome, T. I., Bayne, E. M., Poulin, R. G., Todd, L. D. \& Ford, A. T. 2015. Extreme precipitation reduces reproductive output of an endangered raptor. - Journal of Applied Ecology 52(6): 1500-1508. DOI: $10.1111 / 1365-2664.12510$

Fletcher, K., Howarth, D., Kirby, A., Dunn, R. \& Smith, A. 2013. Effect of climate change on breeding phenology, clutch size and chick survival of an upland bird. - Ibis 155(3): 456-463. DOI: 10.1111/ibi.12055

Franke, A. 2017. Priorities for Gyrfalcon research: food, weather, and phenology in a changing climate. - In: Anderson, D. L., McClure, C. J. W. \& Franke, A. (eds.) 2017. Applied raptor ecology: essentials from Gyrfalcon research. - The Peregrine Fund, Boise, Idaho, USA, pp. 11-32. DOI: 10.4080/are.2017/001

Haest, B., Hüppop, O. \& Bairlein, F. 2017. Challenging a 15-year-old claim: The North Atlantic Oscillation index as a predictor of spring migration phenology of birds. - Global Change Biology 24(4): 1523-1537. DOI: $10.1111 /$ gcb. 14023

Lehikoinen, A., Lindén, A., Byholm, P., Ranta, E., Saurola, P., Valkama, J., Kaitala, V. \& Lindén, H. 2013. Impact of climate change and prey abundance on nesting success of a top predator, the Goshawk. - Oecologia 171(1): 283-293. DOI: 10.1007/s00442-012-2411-z

McDermott, M. E. \& DeGroote, L. W. 2016. Long-term climate impacts on breeding bird phenology in Pennsylvania, USA. - Global Change Biology 22(10): 3304-3319. DOI: 10.1111/gcb.13363

McDonald, G, P., Olsen, P. D. \& Cockburn, A. 2004. Weather dictates reproductive success and survival in the Australian Brown Falcon Falco berigora. - Journal of Animal Ecology 73(4): 683-692. DOI: 10.1111/j.00218790.2004.00842.x

Mearns, R. \& Newton, I. 1988. Factors affecting breeding success of Peregrines in south Scotland. - The Journal of Animal Ecology 57(3): 903-916. DOI: 10.2307/5100

National Oceanic and Atmospheric Administration (NOAA) 2018. - https://www.ncdc.noaa.gov/teleconnections/ nao/ (Last accessed on 2018-02-17) 
NOAA/Climate Prediction Center Internet Team 2012. North Atlantic Oscillation (NAO). NOAA. - http://www. cpc.ncep.noaa.gov/data/teledoc/nao.shtml (Last accessed on 2018-02-16)

Olsen, P. D. \& Olsen, J. 1988. Breeding of the Peregrine Falcon Falco peregrinus. I. Weather, nest spacing and territory occupancy. - Emu 88(4): 195-201. DOI: 10.1071/MU9880195

Öberg, M., Arlt, D., Pärt, T., Laugen, A. T., Eggers, S. \& Low, M. 2015. Rainfall during parental care reduces reproductive and survival components of fitness in a passerine bird. - Ecology and Evolution 5(2): 345-356. DOI: $10.1002 /$ ece3.134

Park, J-S., Fong, A., Chu, V., Holden, A., Linthicum, J. \& Hooper, K. 2011. Prey species as possible sources of PBDE exposures for Peregrine Falcons (Falco peregrinus) nesting in major California cities. - Archives of Environmental Contamination and Toxicology 60(3): 518-523. DOI: 10.1007/s00244-010-9546-x

Parmesan, C. 2006. Ecological and evolutionary responses to recent climate change. - Annual Review of Ecology, Evolution, and Systematics 37: 637-669. DOI: 10.1146/annurev.ecolsys.37.091305.110100

Pipoly, I., Bókony, V., Seress, G., Szabó, K. \& Liker, A. 2013. Effects of extreme weather on reproductive success in a temperate-breeding songbird. - PloS ONE 8(11): e80033. DOI: 10.1371/journal.pone.0080033

Robinson, B. W. \& Prostor, M. 2017. Guidelines for conducting a camera study of nesting raptors. - In: Anderson, D. L., McClure, C. J. W. \& Franke, A. (eds.) - Applied raptor ecology: essentials from Gyrfalcon research. The Peregrine Fund, Boise, Idaho, USA, pp. 283-298. DOI: 10.4080/are.2017/app2

Stocker, T. F., Qin, D., Plattner, G-K., Tignor, M., Allen, S. K., Boschung, J., Nauels, A., Xia, Y., Bex, V. \& Midgley, P. M. 2013. IPCC, 2013: summary for policymakers in climate change 2013. - The Physical Science Basis. Contribution of Working Group I to the Fifth Assessment Report of the Intergovernmental Panel on Climate Change

Sullivan, A. R., Flaspohler, D. J., Froese, R. E. \& Ford, D. 2015. Climate variability and the timing of spring raptor migration in eastern North America. - Journal of Avian Biology 47: 208-218. DOI: 10.1111/jav.00692

Vorkamp, K., Falk, K., Møller, S., Rigét, F. F., Bossi, R. \& Sørensen, P. B. 2017. New and updated time trends of persistent organic pollutants and their effects on eggs of Peregrine Falcons (Falco peregrinus) from South Greenland. - Aarhus University, DCE - Danish Centre for Environment and Energy 249, pp. 80. http://dce2. au.dk/pub/SR249.pdf

Wightman, C. S. \& Fuller, M. R. 2005. Spacing and physical habitat selection patterns of Peregrine Falcons in central West Greenland. - The Wilson Bulletin 117(3): 226-236. DOI: 10.1676/04-036.1

White, C. M., Clum, N. J., Cade, T. J. \& Hunt, W. G. 2002. Peregrine Falcon (Falco peregrinus), version 2.0. In: Poole, A. F. \& Gill, F. B. (eds.) The Birds of North America. - Cornell Lab of Ornithology, Ithaca, NY, USA, DOI: $10.2173 /$ bna. 660

White, C. M., Cade, T. J. \& Enderson, J. H. 2013. Peregrine Falcons of the World. - Lynx Edicions

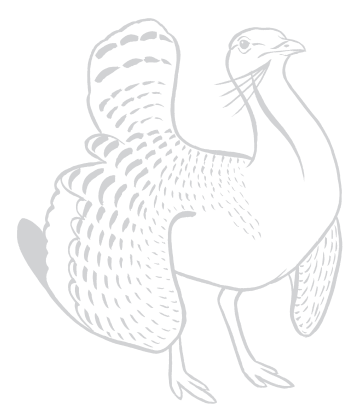

